\title{
PRELIMINARY STUDY OF REDUCING SUGAR PRODUCTION FROM COCONUT HUSK BY ENZYMATIC HYDROLYSIS USING CHITOSAN IMMOBILIZED CRUDE AND COMMERCIAL CELLULOSE
}

\author{
Afan Hamzah $^{1}$ | Muhammad Nurul Hakim ${ }^{1}$ | Baiq Firya Salsabila Safitri ${ }^{1}$ | Nurul Maziyah ${ }^{1}$ | Laila \\ Nur Rahmah $^{1}$ | Hanny F Sangian ${ }^{2}$ | Soeprijanto ${ }^{1}$ | Arief Widjaja*1
}

\footnotetext{
${ }^{1}$ Dept. of Chemical Engineering, Institut Teknologi Sepuluh Nopember, Surabaya, Indonesia

${ }^{2}$ Dept. of Physics, Universitas Samratulangi, Manado, Indonesia

\section{Correspondence}

*Arief Widjaja, Dept. of Chemical Engineering, Institut Teknologi Sepuluh Nopember, Surabaya, Indonesia. Email: arief_w@chem-eng.its.ac.id
}

\section{Present Address}

Gedung Teknik Kimia, Kampus ITS Sukolilo, Surabaya 60111, Indonesia

\begin{abstract}
The objective of this research was to study the production of sugar from coconut husk using immobilized crude and commercial cellulose, including temperature and mixing speed during immobilization. The enzyme from Aspergillus Niger was immobilized on chitosan alone and cross-linked with Glutaric Dialdehyde (GDA). Coconut husk waste was grinded and chemically pretreated using $\mathrm{NaOH} 1 \%(w / v)$. Fourier Transform Infrared Spectroscopy (FT-IR) measurement revealed that enzyme was covalently bonded to the support. Cellulose immobilized on chitosan cross-linked with GDA produced more sugar than immobilized on chitosan alone. Both the crude and commercial enzyme had their yield decreased after immobilization. Despite its less enzyme coupled on micro-sized chitosan, reducing sugar yielded by an immobilized enzyme on micro-sized chitosan had a competitive result with macro-sized chitosan. This may due to decreasing mass transfer resistance when using a smaller size of chitosan. Several important factors such as temperature, mixing speed, and purity of enzyme responsible for the performance of sugar produced from insoluble cellulose using cellulose immobilized on insoluble support was thoroughly discussed.
\end{abstract}

\section{KEYWORDS:}

Coconut Husk, cellulose, Crude, Immobilized, Reducing Sugar 


\section{1 | INTRODUCTION}

Reducing sugar has the potential to be processed into various products such as biofuel, lactic acid, 5-hydroxymethylfurfural, and levulinic acid ${ }^{[1]}$. Coconut husk consists of $26.68 \%$ cellulose, $17.87 \%$ hemicellulose dan $41.2 \%$ lignin, which can be hydrolyzed to form reducing sugar. Enzymatic hydrolysis provides high selectivity, high yields, low energy costs, and mild operating condition. Free cellulose is utilized in this process due to the accessibility of this soluble enzyme to the cellulosic substrates [2]. However, the price of the free enzyme is the main obstacle for its applications. The immobilization of the enzyme could be an effective strategy to enhance its stability and enable the enzyme to reuse and reduce the price ${ }^{3}$.

Polymeric substrates have been commonly utilized as support of immobilization because they have various functional groups and can be easily modified chemically. One polymeric support for enzyme immobilization is chitosan. Chitosan is a cheap, inert, and hydrophilic support. So that it is attractive for enzyme immobilization. The presence of amino groups enables covalent attachment of enzymes ${ }^{4}$. There were two general immobilized methods: chemical methods, where covalent bonds are established between the enzyme and support, and physical methods, where simple physical adsorption procedure is involved. It is one of the most used immobilization methods, but it has drawbacks in the weak interactions between support and enzyme [5]

Immobilization of cellulose on chitosan is affected by temperature and mixing speed during the process. Enzyme operates at its optimum temperature since it becomes idle when the temperature is too low and is denaturized when the temperature is too high. Mixing speed is vital to provide good contact and reaction during immobilization, but vigorous mixing speed makes the enzyme denatures due to shear $[6$.

Many studies have been conducted to immobilize cellulose in chitosan ${ }^{[7][8}$. But the substrate used in those studies was generally soluble cellulose, such as carboxymethyl cellulose (CMC). There was no comprehended study about the effect of immobilization conditions such as temperature and mixing speed. The utilization of crude enzymes and the addition of cross-linking substances have not been studied. This study outlines immobilization of enzyme into chitosan and chitosan cross-linked with GDA, hydrolysis of CMC and coconut husk waste and using the immobilized and free enzyme and investigated the effect of Several important factors responsible for the performance of sugar produced, i.e. temperature, mixing speed, and purity of enzyme.

\section{2 | MATERIAL AND METHOD}

\section{1 | Material}

Coconut husk was gained from Sulawesi, Indonesia. Coconut husk was pretreated mechanically and chemically. It was grinded, dried, and sieved to $100-120$ mesh. Then, it was pretreated with $\mathrm{NaOH} 1 \%(\mathrm{w} / \mathrm{v})$ for $16 \mathrm{~h}$ at $80^{\circ} \mathrm{C}$. After that, it was washed using hot water and dried again for 24 hours at $60^{\circ} \mathrm{C}$ Aspergillus niger strain was from Biochemical Laboratory, ITS Surabaya, Indonesia. Potato Dextrose Agar, Yeast extract, Glucose, Bovine Serum Albumin, Coomassie Briliant Blue, Sodium citric, $\mathrm{NaOH}$, Citric acid, $\mathrm{CH} 3 \mathrm{COOH}$, CH3COONa, Glutaric dialdehyde (GDA) were obtained from Merck, Germany. Chitosan flake technical grade was from PT. KIMINDO, Surabaya, Indonesia. Dinitro salicylic acid, Chitosan, CMC (carboxymethyl cellulose), Magnetic powder (Fe3O4), Commercial cellulose from Aspergillus niger were purchased from Sigma-Aldrich, Germany. Crude cellulose was produced based on procedure introduced in ${ }^{[0}$ using rice straw as a substrate.

\section{2 | Preparation of Microparticle and Nanoparticle}

Chitosan magnetic microparticles were prepared using the method ${ }^{[10]}$ with some modification. Four grams of chitosan and 8 grams of magnetite particles were added in $200 \mathrm{~mL}$ of $0.2 \mathrm{M}$ acetic acid. After they were completely dissolved, $1 \mathrm{M} \mathrm{NaOH}$ was added excessively to convert the solution into an insoluble magnetic chitosan microparticle. Chitosan nanoparticle was made as to the same concept of microparticle ${ }^{111}$. 


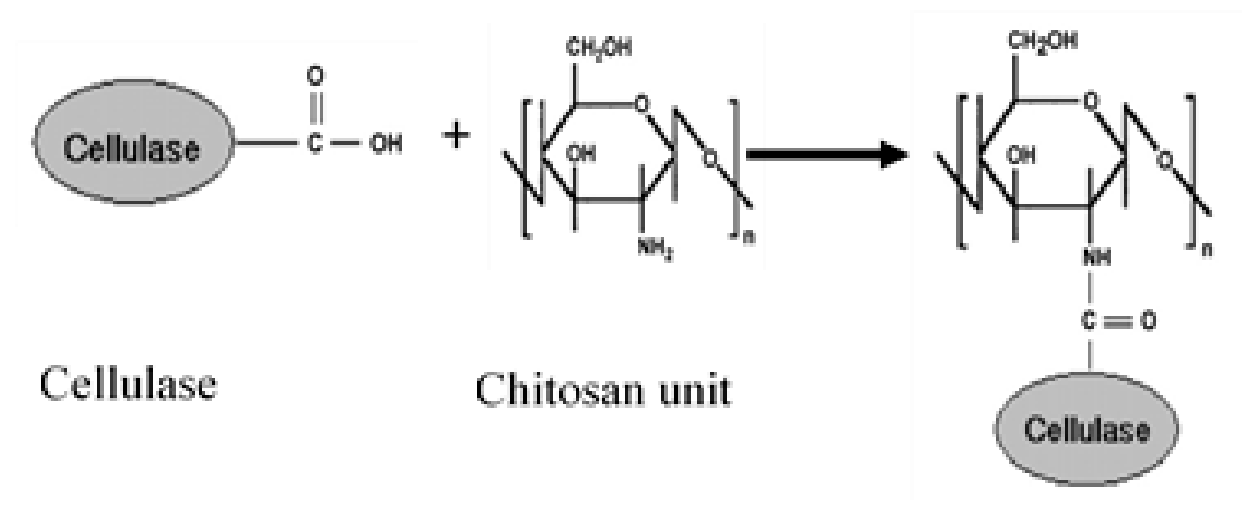

FIGURE 1 A covalent bond formed between cellulose and chitosan.

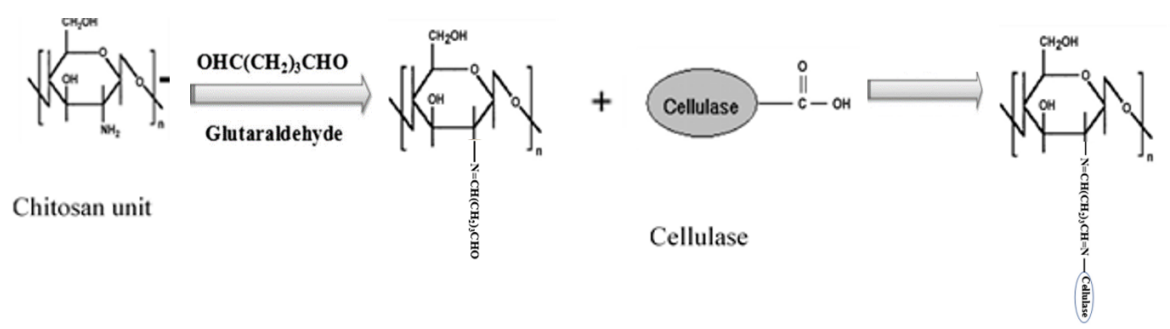

FIGURE 2 A covalent bond formed between cellulase and chitosan + Glutaral dialdehyde (GDA).

\section{3 | Preparation of GDA + Chitosan}

The $0.1 \mathrm{~g}$ Chitosan was added to a $10 \mathrm{ml} 1 \%$ (v/v) GDA solution. It was kept in shaking incubator at $25^{\circ} \mathrm{C}, 125 \mathrm{rpm}$ for $4 \mathrm{~h}$, and left at $25^{\circ} \mathrm{C}$ without shaking for $12 \mathrm{~h}$. The chitosan that had been cross-linked was filtered and washed with phosphate buffer $\mathrm{pH}$ 7.

\section{4 | Immobilization of Enzyme}

The $0.1 \mathrm{~g}$ Chitosan or Chitosan+GDA were supplemented to the enzyme solution, and the immobilization reaction was executed for $24 \mathrm{~h}$ at $\left(20,30,37^{\circ} \mathrm{C}\right)$ in incubator shaker $(100,125,175 \mathrm{rpm})$. The precipitates were separated and washed with phosphate buffer (pH7). They were stored at $4^{\circ} \mathrm{C}$ until use.

\section{5 | Hydrolysis}

The $0.1 \mathrm{~g}$ immobilized cellulose was added to $1 \mathrm{~g}$ pretreated coconut husk in $20 \mathrm{ml} 0.1 \mathrm{M}$ citric buffer $\mathrm{pH}$ 3. Hydrolysis was done in shaker incubator $35^{\circ} \mathrm{C}, 125 \mathrm{rpm}$ for 48 hours. The same method was also used for $2 \mathrm{ml} 1 \%$ Carboxymethyl Cellulose (CMC) but only for 10 minutes.

\subsection{Determination of Enzyme Stability}

The $0.1 \mathrm{~g}$ immobilized cellulose and free cellulose containing the same amount of protein as the immobilized one was mixed with $2 \mathrm{ml}$ of $1 \% \mathrm{CMC}$. It was reacted at $\mathrm{pH}(3,4,5.5,7$ and 10$)$ and $\left(15^{\circ}, 30^{\circ}, 35^{\circ}, 45^{\circ}, 50^{\circ}, 60^{\circ} \mathrm{C}\right)$ temperature. 


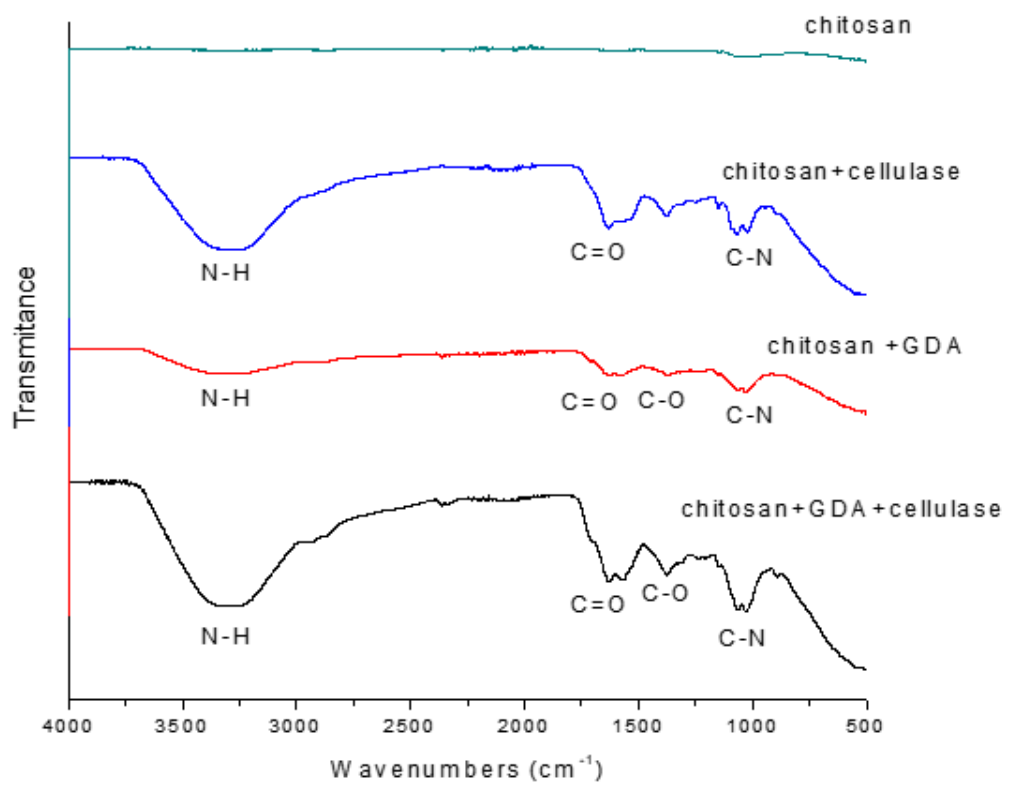

FIGURE 3 FTIR spectra of chitosan immobilized cellulose.

\section{7 | Analytical Method}

Using the Bradford method, the unbound enzymes were determined using Bovine Serum Albumin (BSA) as a standard solution. Reducing sugar was analyzed by Dinitro salicylic acid (DNS) method to obtain the concentration of sugar. FT-IR spectra are measured using FT-IR spectrometer (Thermo Scientific, US)

\section{3 | RESULTS AND DISCUSSION}

\section{1 | Characterization of The Immobilized Enzyme by FT-IR}

From previous research conducted ${ }^{[5]}$, the reaction between chitosan and cellulose is described as in Figure 1 and chitosan+GDA in Figure 2 It can be seen from the figure that amino groups of chitosan were bonded directly with the carboxylic terminal residue in the enzymes.

This reaction is also confirmed with Fourier Transform Infrared (FT-IR) spectra, as shown in Figure 3 spectra from chitosan and enzyme immobilized on chitosan. From those figures, there was a significant change of the peak in wavelength 3272.53 $\mathrm{cm}-1$ that is characteristic of the amino group $(\mathrm{N}-\mathrm{H})$, wavelength $1632.67 \mathrm{~cm}-1$ that is characteristic of $\mathrm{C}=\mathrm{O}$, and wavelength $1080 \mathrm{~cm}-1$ that is characteristic of (aliphatic amide) $\mathrm{C}-\mathrm{N}^{12}$. These indicate that enzymes have been immobilized on chitosan.

FT-IR spectra of enzyme immobilized on chitosan-GDA can be seen in figure 3 In that figure, there are also some significant change of peak in wavelength $3267.54 \mathrm{~cm}-1(\mathrm{~N}-\mathrm{H}), 1629.15 \mathrm{~cm}-1(\mathrm{C}=\mathrm{O}), 1027.66 \mathrm{~cm}-1(\mathrm{C}-\mathrm{N})$ which is same as cellulosechitosan and wavelength $1376.0 \mathrm{~cm}-1$ (C-O) that indicated GDA as cross-linking agent and spacer arm in covalent bonding.

\section{2 | Effect of Temperature, Solubility, and Mixing Speed on Immobilization Process}

Table 1 and Table 2 exhibit the sugar resulted from CMC and Coconut Husk as the substrate with immobilized cellulose prepared in several operating conditions. Immobilized cellulose prepared at $30^{\circ} \mathrm{C}$ yielded more Sugar from $\mathrm{CMC}$ as a substrate than the one that prepared at $20^{\circ} \mathrm{C}$. The effect of mixing speed was studied under the same $30^{\circ} \mathrm{C}$ to $37^{\circ} \mathrm{C}^{6}$. The study shows that it loses its biocatalytic activity ${ }^{113}$. Thus, the enzyme inactivation and denaturation caused by shear did not happen at $175 \mathrm{rpm}$. 
TABLE 1 Reducing sugar result by cmc using cellulase immobilized on chitosan.

\begin{tabular}{ll}
\hline $\begin{array}{l}\text { Immobilization } \\
\text { Condition }\end{array}$ & $\begin{array}{l}\text { Reducing } \\
\text { Sugar }(\mathbf{m g} / \mathbf{L})\end{array}$ \\
\hline $200 \mathrm{C}, 100 \mathrm{rpm}$ & 102.278 \\
$30 \mathrm{0C}, 100 \mathrm{rpm}$ & 162.715 \\
30 0C,125 rpm & 357.973 \\
\hline
\end{tabular}

TABLE 2 Reducing sugar result by coconut husk as substrate.

\begin{tabular}{lll}
\hline Support & $\begin{array}{l}\text { Immobilization } \\
\text { Condition }\end{array}$ & $\begin{array}{l}\text { Reducing } \\
\text { Sugar }(\mathbf{m g} / \mathbf{L})\end{array}$ \\
\hline chitosan & $370 \mathrm{C}, 175 \mathrm{rpm}$ & 387.53 \\
& 30 0C, 125 rpm & 144.119 \\
chitosan GDA & $370 \mathrm{C}, 175 \mathrm{rpm}$ & 1559.69 \\
& $300 \mathrm{C}, 125 \mathrm{rpm}$ & 288.238 \\
\hline
\end{tabular}

\section{3 | Effect of Enzyme Purity in Sugar Production}

TABLE 3 The yield of reducing sugar from free enzyme and immobilized enzyme that is made in $37^{\circ} \mathrm{C}$ and 175 rpm.

\begin{tabular}{lc}
\hline Enzyme Type & $\begin{array}{c}\text { Reducing } \\
\text { Sugar }(\mathbf{g} / \mathbf{L})\end{array}$ \\
\hline Free crude enzyme & 1.290 \\
crude immobilized on chitosan & 0.453 \\
Commercial cellulase & 4.130 \\
Commercial cellulase immobilized on & 0.570 \\
chitosan & \\
\hline
\end{tabular}

TABLE 4 Reducing sugar produced from different size of chitosan.

\begin{tabular}{lll}
\hline Immobilized Enzyme & $\begin{array}{l}\text { Bonded } \\
\text { Enzyme }(\mathbf{m g})\end{array}$ & $\begin{array}{l}\text { Reducing } \\
\text { Sugar }(\mathbf{m g} / \mathbf{L})\end{array}$ \\
\hline Macro sized chitosan & 38.35 & 0.57 \\
Micro sized chitosan & 5.50 & 0.507 \\
Nano sized chitosan & 4 & 0.49 \\
\hline
\end{tabular}

Various types of enzymes were applied as a biocatalyst to convert coconut husk to reducing sugar. Table 3 shows the sugar yielded by each type of enzymes. A free crude enzyme produced less sugar than the commercial cellulose. This is because the enzyme contained substances other than celluloses. The absence of celluloses allows the enzyme to hinder hydrolysis. After the enzymes were immobilized, the immobilized crude enzyme was able to maintain $35 \%$ of its productivity. It was more significant than the immobilized commercial cellulose, which could only maintain its activity at $12 \%$. This result indicated that the crude enzyme made in our laboratory has an excellent prospect to applied as immobilized enzymes. The drawback of crude enzyme application on immobilization was its composition, which contained not only a single type of enzymes, which made it challenging to observe the substance that was immobilized on a support.

\subsection{Effect of Particle size of The Support}

Chitosan, as support for immobilization, was modified to be macro-sized, micro-sized, and nano-sized. As described in the material and methods section, the microparticles were synthesized by dissolving and magnetite chitosan in acetic acid. $\mathrm{NaOH}$ was then added to the solution, which transformed it to be chitosan microparticles, which magnetite entrapped in it. The nanoparticles had the same concept as microparticles. The difference was in the size of the magnetite used. Chitosan macroparticles did not have a particular way of creating them. The microparticles had $<500 \mu \mathrm{m}$ in diameter size, while macroparticles had $>1000 \mu \mathrm{m}$ and the nanoparticles had $<20 \mathrm{~nm}$. Table 4 shows the performance of cellulose immobilized on different sizes of chitosan. The competitive result was shown although the micro-sized and the nano-sized had less coupled. It was due to smaller size particle provide larger surface area and numerous active sites available for the cellulose molecules to be coupled [10 [14].

\section{5 | Temperature and pH Stability of The Immobilized Enzyme}

To study the stability of the enzyme, a commercial cellulose from Aspergillus Niger immobilized on chitosan nanoparticle, and its free form was used. The cellulose was used for hydrolysis carboxymethyl cellulose (CMC). Figure 4 shows that immobilized cellulose had optimum activity at $\mathrm{pH} 5.5$, but the other $\mathrm{pH}$ did not have any difference inactivity. The free enzyme shows maximum activity at $\mathrm{pH}$ four but shows big differences with the other $\mathrm{pH}$. The same pattern also applied to temperature stability. The immobilized enzyme had more wide range temperature than the free enzyme. This was caused by the transformation 


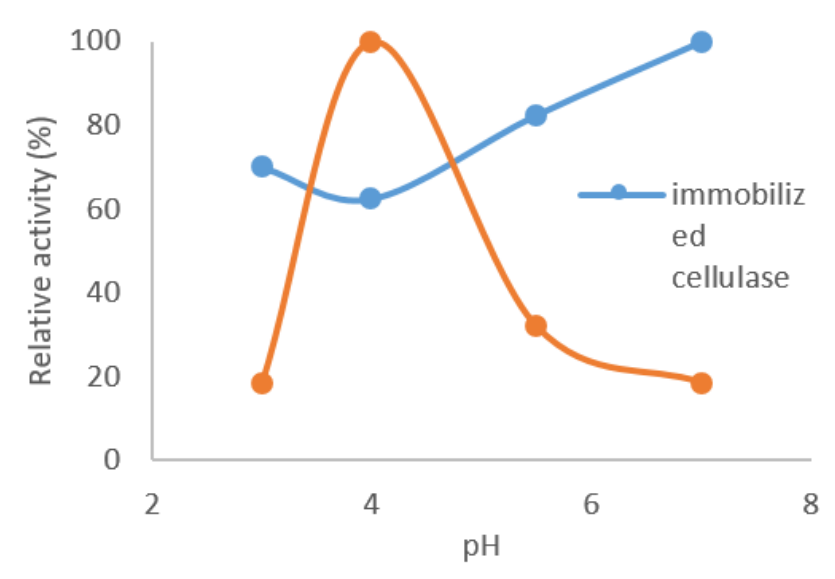

FIGURE 4 Effect $\mathrm{pH}$ in hydrolysis CMC.

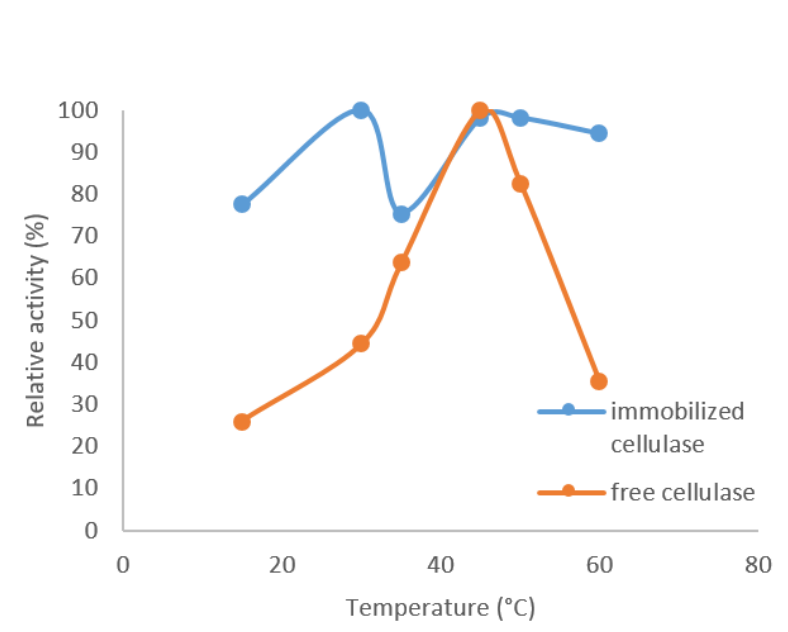

FIGURE 5 Temperature vs relative activity in hydrolysis CMC.

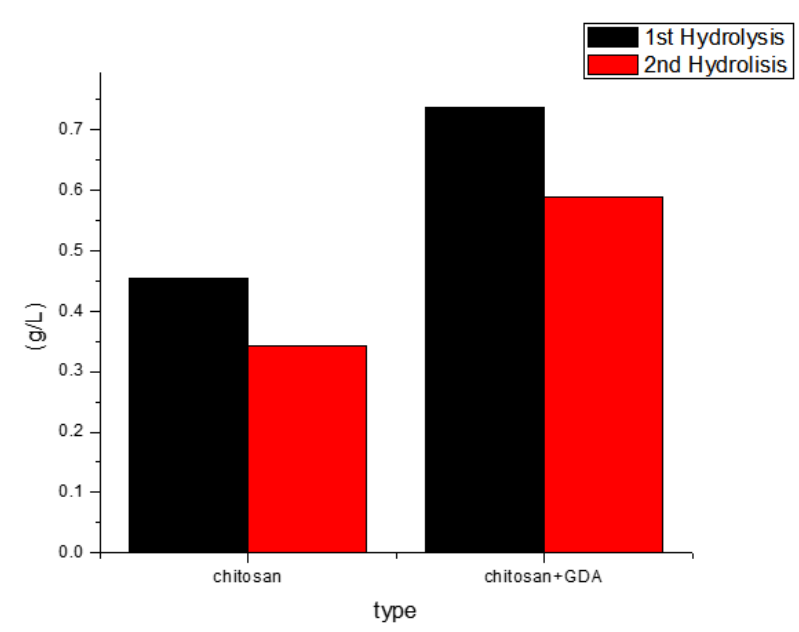

FIGURE 6 Temperature vs concentration in concentration in hydrolysis CMC.

of the physical and chemical properties of the enzyme. The covalent bond formation might also reduce the conformational flexibility and may result in higher activation energy for the molecule to re-organize the proper conformation for binding to the substrate. [5] [15] [16].

\section{6 | Reusability}

Reusability is the main advantage of immobilization. Figure 4 shows the reusability of immobilized cellulose on chitosan and chitosan+GDA. After two times hydrolysis, chitosan and chitosan GDA maintained $75.31 \%$ and $79.94 \%$ of its activity, respectively. This outcome proved that the immobilized enzyme could be used repeatedly to increase productivity and reduce the overall cost. Effect temperature in hydrolysis CMC can be seen in Figures 5 and 6 


\section{4 | CONCLUSION}

These preliminary studies describe an enzyme immobilization in chitosan for hydrolyzing carboxymethylcellulose (CMC) and coconut husk (insoluble cellulose). This study also describes the critical variable of enzyme immobilization that affects the reduction of sugar production. The temperature and mixing speed of the immobilization process changed, improving enzyme binding in support. The addition of cross-linker, Glutaral dialdehyde (GDA), enhance the yield of reducing sugar. Both crude enzyme and commercial cellulose have their yield of sugar decreased after immobilization. Coconut husk, as a substrate, has good prospects in the application of immobilized enzymes in the production of reducing sugar. Despite its low sugar yield, immobilized enzymes offer their ability to be used repeatedly so that the process becomes inexpensive.

\section{5 | ACKNOWLEDGMENT}

The authors are grateful to the Directorate General of Resources for Science, Technology, and Higher education, Ministry of Research, Technology, and Higher Education of Republic Indonesia to give funding for this study.

\section{References}

1. Ramli NAS, Amin NAS. Catalytic Hydrolysis of Cellulose and Oil Palm Biomass in Ionic Liquid to Reducing Sugar for Levulinic Acid Production. Fuel Processing Technology 2014;128:490-498.

2. Podrepsek GH, Primozic M, Knez ZK, Habulin M. Immobilization of Cellulase for Industrial Production. Chemical Engineering Transactions 2012;27:235-240.

3. Siti Sabrina Mohd Sukri MSAM. Combination of Entrapment and Covalent Binding Techniques for Xylanase Immobilisation on Alginate Beads: Screening Process Parameters. Chemical Engineering Transactions 2017;56:169-174.

4. Akkus Cetinus S, Nursevin Oztop H. Immobilization of Catalase Into Chemically Crosslinked Chitosan Beads. Enzyme and Microbial Technology 2003;32(7):889-894.

5. El-Ghaffar MAA, Hashem MS. Chitosan and Its Amino Acids Condensation Adducts as Reactive Natural Polymer Supports for Cellulase Immobilization. Carbohydrate Polymers 2010;81(3):507-516.

6. Jaspe J, Hagen SJ. Do protein Molecules Unfold in a Simple Shear Flow? Biophysical journal 2006;91(9):3415-3424.

7. Ahirwar R, Sharma JG, Nahar P, Kumar S. Immobilization Studies of Cellulase on Three Engineered Polymer Surfaces. Biocatalysis and Agricultural Biotechnology 2017;11:248-251.

8. Mao X, Guo G, Huang J, Du Z, Huang Z, Ma L, et al. A novel Method to Prepare Chitosan Powder and its Application in Cellulase Immobilization. Journal of Chemical Technology and Biotechnology 2006;81(2):189-195.

9. Arief Widjaja, Evi Noerista Lestari, Akbar Tanjung, Widian, Alfian HO. Optimized Production of Xylanase From Fungal Strains and Its Purification Strategies. Journal of Applied Sciences in Environmental sanitation 2009;4(3):219-232.

10. Biro E, Neme, Th AS, Sisak C, Feczko T, Gyenis J. Preparation of Chitosan Particles Suitable for Enzyme Immobilization. Journal of biochemical and biophysical methods 2008;70(6):1240-1246.

11. Zang L, Qiu J, Wu X, Zhang W, Sakai E, Wei Y. Preparation of Magnetic Chitosan Nanoparticles as Support for Cellulase Immobilization. Industrial and Engineering Chemistry Research 2014;53(9):3448-3454.

12. Mistry BD. A Handbook of Spectroscopic Data: UV, IR, PMR, CNMR and Mass Spectroscopy. 1 ed. Jaipur, India: Oxford Book Company; 2009. 
13. Lu-E Shi, Zhongxiu Tang, Yu Chu Yi, Jianshu Chen, Wen-yue Xiong GY. Immobilization of Nuclease p1 on Chitosan Micro-Spheres. Chemical and Biochemical Engineering Quarterly 2011;25(1):83-88.

14. Han J, Rong J, Wang Y, Liu Q, Tang X, Li C, et al. Immobilization of Cellulase on Thermo-Sensitive Magnetic Microspheres : Improved Stability and Reproducibility. Bioprocess and Biosystems Engineering 2018;41:1051-1060.

15. Jaquelina Sanchez-Ramirez, Jose L Martinez-Hernandez, Patricia Segura-Ceniceros, Guillermo Lopez, Hened Saade, Miguel A Medina-Morales, Rodolfo Ramos-Gonzalez CNA\&AI. Cellulases Immobilization on Chitosan-Coated Magnetic Nanoparticles: Application for Agave Atrovirens Lignocellulosic Biomass Hydrolysis. Bioprocess and Biosystems Engineering 2017;40(1):9-22.

16. Alahakoon T, Koh JW, Chong XWC, Lim WTL. Immobilization of Cellulases on Amine and Aldehyde Functionalized Fe2O3 Magnetic Nanoparticles. Preparative Biochemistry and Biotechnology 2012;42(3):234-248.

How to cite this article: Hamzah A., Hakim M.N., Safitri B.F.S., Maziyah N., Rahmah L.N., Sangian H.F., Supriyanto S., Widjaya A., (2020), Preliminary Study of Reducing Sugar Production from Coconut Husk by Enzymatic Hydrolysis Using Chitosan Immobilized Crude and Commercial Cellulose, IPTEK The Journal of Technology and Science, 31(1):67-74. 